\title{
Commentary
}

\section{Headhunting as Reflexive Violence}

\author{
Arne Røkkum \\ University of Oslo
}

\begin{abstract}
This is a commentary article on existing anthropological views on headhunting practices. Its focus is an article by Mikkelsen (2017) in this journal, 'Facehunting: Empathy, Masculinity and Violence among the Bugkalot.' The commentary article sees value in Mikkelsen's critical stance on the issue of extreme violence, such as headhunting not entailing a prior dehumanization of the victim. 'Headhunting as Reflexive Violence' addresses an issue of 'selective empathy,' and concludes that in light of the Bugkalot ethnography and impulsive headhunting, the discussion point could be one, following Persson and Savulescu (2017), of 'reflexive empathy.' The article argues that attention should be given to the material, plastic, and tonal practices celebrating and possibly even eliciting the kill. These might provide us with a rare window into the way cultural techniques can embellish violence.
\end{abstract}

Keywords Bugkalot, Ilongot, headhunting, sacrifice, empathy, masculinity, violence aestheticization, Mikkelsen

The [Bugkalot] men were fully armed with spears, bows and arrows, shields, and head-knives; geestrings apart, they were naked. Some of them wore on the head the scarlet beak of the hornbill; these had taken heads.

(Willcox 1912, 6)

\section{Headhunting in Words and Action}

As with other topics of recent interest, such as animism, the issue of headhunting may open up for a broader ontological evaluation. A review of the theme would include the following key contributors: Aswani 2000, Barton 1919, Bloch 1992, Chacon and Dye 2007, De Raedt 1996, Downs 1955, Furness 1902, George 1996 a \& b, Hocart 1922, Hollan 2011, Hoskins 1996, Kruyt 1906, Lumholtz 1991, McGovern 1922, McKinley 1976, McKinnon 1991, Needham 1976, Roque 2010, M.Rosaldo 1980, R. Rosaldo 1980, Rousseau 1990, Siverts 1978, Tsing 1996, Valeri 1994, van der Kroef 1952, Waite 2000, Yang 2011.

Ethnographies from the Southeast Asian region inform us about ritualized violence for modulating generative balances between the sexes and between neighboring peoples. At the time when headhunting was still practiced in the Luzon Cordilleras, Barton writes: 'The war was carried on as a series of head-takings' (Barton 1919, 177). Facehunting's focus on the biographic aspect of headhunting provides a contrast to those writings that highlight such larger formats of colonial geopolitics and regional power play (e.g. Black 1976, 31, R. Rosaldo 1980, Tsing 1996, 189). Mikkelsen's contribution (Mikkelsen 2017) based on fieldwork among the Bugkalot in the Cordilleras of Luzon, aligns with a 
critical stance formulated by Rousseau: 'headhunting is more than an epiphenomenon of warfare' (Rousseau 1990, 275).

The Rosaldos address the topic of headhunting among the Bugkalot (Ilongot) with material from fieldworks beginning in the late 1960s. They shed light on the emotive contexts of the kill. However, the addition of Mikkelsen's view - also one which lays out the emotive enactment of eruptive violence - is not redundant. There can hardly be any final answer to what headhunting is about - no closure.

'Headhunter' as a descriptor affixes itself also to travelogue authorship, with the typical words 'among so-and-so headhunters' in the title line. Let me quote here one example from an ethnography in the northernmost part of the Austronesian world, the aborigines of Formosa (Taiwan). A book on the topic of headhunting was published in 1922 by Janet B. Montgomery McGovern. Its Preface bears the signature of an Oxford anthropologist and proponent of a pre-animist stage in the formation of religion, Robert Ranulph Marrett. The book's title: Among the Headhunters of Formosa. The frontispiece has a photo of a Yami couple, from Lan Yu (Botel Tobago / Orchid Island). The man wears a helmet, and he has a firm grip on a machete. The photo may have been included as an apropos to the title line: hinting at the possibility of severing heads. But since this is an illustration identifying a woman and man in what is tagged as the 'Yami tribe,' it is hardly conceivable that any heads have been chopped off. I observed a scenario such as portrayed by the helmeted man in 1979 (Røkkum 1991). The conically shaped, layered metal helmet with square apertures for eyesight is for protection against bad anitu spirits, not against bad humans. The machete is for charging at these spirits. On the face of it, bellicose, but only if cutting the image off from the anthropological grid foisted upon it. The opening line in the Preface of McGovern written by Marrett foregrounds the anthropological authorship itself: 'they [the headhunters] welcomed her with a respect that bordered on veneration' (McGovern 1922, 9). Marrett says that the book is for the 'general public' (McGovern 1922, 13). A fuller digest, he assures, has to come in future work.

Popular allure about the outlandish may adumbrate ethnography. Even where the notes on headhunting are sparse, the title line makes it a pars pro toto (cf. e.g. Haddon 1901). Headhunting, to no lesser extent than cannibalism and sacrifice, is up to this day a badge of savagery in popular imagination. For an update, see Millman (1998). His book is promoted as having been written 'by a guy who likes to get around.' The title gives a feel of the quaintness of exploration: An Evening Among Headhunters \&O Other Reports from Roads Less Traveled.

In the early years of American administration of the Philippines, around 1909, savagery was elicited and embedded in the very reasons for governing. Lieutenant-Colonel-cumProfessor Cornèlis de Witt Willcox had a reason good enough for suggesting that that headhunters of the Luzon Cordilleras deserved protection: from the rage vented against them by Christians lowlanders. In 1912, he published a survey of Cordillera groups: The Head Hunters of Northern Luzon: From Ifugao to Kalinga - A Ride through the Mountains of Northern Luzon. The final line of the title reads as follows: With an Appendix on the Independence of the Philippines. That was precisely what he did not want, so he had gone out into the Cordillera of Luzon on horseback to establish rapport (or perhaps an author's empathetic understanding, cf. above, McGovern 1922 and in a methodological outlook, Wikan 2013). Willcox noted that headhunting among these Cordillera groups targeted 
people also on the outside, such as Christian lowlanders and Negritos. Renato Rosaldo (1980) describes feuding within the Cordillera region, he makes no mention of an incursion into the area by Willcox.

No allure, not even through such familiar terms as 'sacred violence' is to be detected in Mikkelsen's Facehunting. The essay defrocks the cultural sublimity of violence and its study by deploying the term 'murder.' He compares headhunting among the Bugkalot to head trophy-taking in World War II theaters. Hoskins pursues a similar, open-ended view, of heads taken as trophies in warfare and as specimen in science (see Hoskins 1996, and for a view on colonialism, Roque 2010).

Mikkelsen's focus on 'prereflexive' empathy differs from the cultural relativism that imbues the work of Michelle Rosaldo (1980), who filters Bugkalot emotion through the Bugkalot gloss on human interiority she harvested in fieldwork. In her reportage, 'Ilongots [Bugkalots] explain themselves - how they feel and why they used to kill' (Rosaldo 1980, 36). Facehunting suggests that the Rosaldos may have neglected the complexities of headhunting by seeing it as a 'traditional practice' (Mikkelsen 2017, 11). A key term for Mikkelsen, with his focus on unfiltered, personal, experience is that of transgression: through murder and the personal costs for the perpetrator. Mikkelsen seeks out the point of view of the headhunter himself and the transgressive reactions shown in reminiscences of the past. Violence - contra M. Rosaldo - is not the outcome of prior dehumanization.

The case of dehumanization is neither a priori in the case of punitive killings according to Fiske and Rai. For a perpetrator to 'feel pain, shame, humiliation, disgrace, or the fear and horror of dying' she/he needs rather be 'humanized' (Fiske and Rai 2015, 158, emphasis in the original). In other words, the punisher wants the perpetrator to experience empathy, before being put to death.

\section{Enculturating Violence}

If broadening the view to take into account ethnographic and historical records, headhunting was practiced as part of warfare in the Philippines. Yang (2011) adduces the more recent example of skirmishes in the Luzon Cordilleras with rebels of the NPA (New People's Army). The issue of humanizing or dehumanizing the victim was simply not relevant when the ethnographic case was war rather than headhunter's expedition. Bugkalot environs were populated with declared adversaries: hostile clans and hostile Christian lowlanders. Within the perspective of this broader format, a boy's initiation to the feat of decapitation might even be seen as a demonstration of prowess and coordination for a role as a warrior and as a hunter. The first kill (it seems that no more than one kill was expected) might simply be a test of manhood similar to the first kill, of game, among hunters. Collier and Rosaldo (1981, 302) comment on M. Rosaldo's ethnography; they emphasize the metaphoric match between taking heads and hunting. Headhunting could have been an abiding aspect of the lifecycle of the male Bugkalot, of growing up. Yang quotes informant recollections about playing headhunting games in childhood (Yang 2011, 162). In Yang's paraphrase of headhunters' reminiscences, one line reads like this: 'women always giggle and comment that the heads must have been very smelly (enamoy)' (Yang 2011, 183, endnote 14). R. Rosaldo writes: 
Volatile, envious, passionate (at least according to their own cultural stereotype of the unmarried man [bunintaw]), they constantly lust to take a head (Rosaldo 2004, 175).

In Mikkelsen's portrayal, there is only a slight element of cultural stereotype: in the postmortem defamation of the head. Mikkelsen draws a picture of a visceral terror causing vomiting and even fainting in the chaotic situation of the kill (Mikkelsen 2017, 11). Heads were left in the bush without further ado, and the recognition of the feat did not initiate the cutter into any distinctive status set. However, Mikkelsen and M. Rosaldo mention something like an ennui among young men. In M. Rosaldo's portrayal, it is exacerbated by innuendo coming from initiated elders (Willcox 1912, 72 records a similar trait.) In Mikkelsen's portrayal, enervation is exacerbated by innuendo coming from in-laws in matrilocal settings. What seemingly traumatizes a man is not yet having achieved the kill.

Then what happened after the kill? Facehunting makes no mention of an ear pendant formed by the scarlet beak of a hornbill (Willcox 1912, 62; Yang 2011, 163); this artifact could possibly convey an epitome of maleness. Yang reports that the US based New Tribes Mission present in her area of fieldwork since the late 1950s expected the Bugkalot churchgoers to stop wearing the ear pendant. The missionaries realistically perceived it as the referent of a kill. Chopping off a head may be an ephemeral act for the Bugkalot; it is dumped in the bush. The material and permanent concomitant of the deed, it seems, is one of a crimson pendant dangling from the upper cartilage of the boy's ear. Further ethnographic detail might even suggest that its red color encapsulates an image of the victim's blood.

Tossing the head in the bush can be seen as 'transgressive,' although in a slightly different sense than in Facehunting: as a preamble to the sexual freedom of male adulthood. Sexuality can be no less 'prereflexive' than the kind of empathy that, in Mikkelsen's account based on informant recollections, has visible, visceral effects. De Raedt on the Kalinga writes about the 'extraordinary attractiveness' (De Raedt 1996, 175) of the headhunter and women offer him 'love gifts' (De Raedt 1996, 176). A 'love gift' presented by a married woman would be tantamount to adultery. The return from the killing is not only a moment of pitched emotion; it also suspends normal prudence between the sexes. Ritualized transgression seems to have taken place during the celebratory feast afterward, the buayat (Yang 2011, 161). Willcox gives a close-up view of a Bugkalot dance rehearsed in honor of his Cordillera mission (Willcox 1912, 66-68). In one sequence, the male dancers charge at each other with 'head-knives,' the instruments used for chopping heads. The act of the kill is sublimated as the defining act of manhood.

Even in a broader, comparative view on headhunting, we can discern how transgression, even when it involves sexuality, is scripted in some way. Among the Toradja of Sulawesi, as described by George (1996a, 76), the adulation of a woman for her husband's headhunting success is delivered in solo song recital. Metcalf writes about rules that are broken among the Berawan of Borneo in the aftermath of the kill: sexual license is welcomed (Metcalf 1982, 132). So lewd was the women's dance that informants could only divulge its occurrence by innuendo and rolling eyes. Roth reviews accounts of headhunting in Borneo, mainly among the Dayak and the Dusun. One line reads as 
follows: 'It was absolutely necessary to be the possessor of one head before marriage' (Roth 1896 [vol. 2], 164, emphases in the original). The Bugkalot case stipulates the same requirement, one head, and as in Borneo: no requirement of demonstrated valor in the act itself of the kill (the head of a defenseless victim is as good as the head of an ambushed, armed enemy). Also in the Luzon Cordilleras, the Kalinga adhered to the same tendency toward undiscerning head-taking (De Raedt 1996, 172).

Among peoples in the Cordilleras, it may be the ritualized tossing of the head that releases the sign of hyper-masculinity. Mikkelsen's argument that there is no dehumanization of the victim is plausible in light of this. Ritualization, either by tossing the severed head or by ornamenting it as in Borneo, makes it a dialogical subject for the killer and maybe even for a whole settlement. But this dialogue, even when accompanied by food and drink provisions, may not sustain empathy in the long run.

In the Solomon Islands, dehumanization of trophy skulls from raided populations on other islands - demonstrated their 'ultimate alienation' (Aswani 2000, 62). With pronounced parallelism, headhunters incurred identities of fish and pigs. Valeri, for the East Indonesian Huaulu, expands such equivalence to the hunt for game: 'the human victim is strongly assimilated to a hunted wild animal' (Valeri 2000, 113). Skulls on display were insignia of valor; Hocart (1922) offers a record of the materiality of this, of dedicated 'skull-houses.' Waite (2000) has made a close-up study of such pageantry of the headhunt. In the present day of backpacking tourism, visit at a few skull repositories incurs 'custom fees' (Hviding 1998, 39). Back in 1898-99, A.C. Haddon, on his expedition in Sarawak, observed a ceremonial demand for heads somewhat above what was available in local stashes. Rajah Brooke favored recirculation rather than taking fresh heads. He recognized the need for setting up governmental repositories, where heads could be borrowed according to need. Haddon writes: 'These skulls are labelled A, B, C, etc., and a record is kept of each borrowing transaction' (Haddon 1901, 395). No lack of benevolent colonial exactitude here, an inventory of human material may have seemed like a library's invention of reading material.

\section{The Abiding Allure}

The Bugkalot's interaction with the head takes place in a brief instant, just tossing it. In this brittle situation, I infer, any prereflexive experience of empathy might compromise one's quality as hunter or warrior. Bona fide rituals of transition may call for cultural rules to be shattered for an instant. In the portrayed instance of the headhunter's kill, there may be horror but only in a moment along a temporalized path toward adulthood. The act of tossing the head is overtly transgressive, a visceral revolt even if it simply reifies a cultural artifact of manhood to be proved. The disarray of the kill itself appears to have been replaced with fulfillment in a rather scripted celebratory feast buayat (not mentioned by Mikkelsen). M. Rosaldo emphasizes the qualification for manhood aspect; Mikkelsen de-emphasizes it.

In the wider view of Southeast Asian ethnographies, one might ask, however: Why do people not want to bury their past? According to McKinnon, the Tanimbarese of East Indonesia abandoned headhunting when subjugating themselves to the Dutch rule early in the $20^{\text {th }}$ century (McKinnon 1991, 8 [incl. ftn. 6]). But even so, the awareness of the practice, including the fears, would still live on during its 'season,' the dry period of the year. In other places in Southeast Asia, the awareness may live on in oral and plastic 
culture, through the usage of mock heads such as coconuts, effigies - and even in the dressing old heads in palm leaves to make them look realistic (cf. George 1996b.) Among the Kalinga, even a headhunter's knife receives celebratory attention: a fetish may be born (De Raedt 1996). But unlike what is the case in Sulawesi (George 1996b), the celebratory songs that might leave hints about a valorization of cutting heads have seemingly not been transcribed by ethnographers. Hocart, however, makes an exception to this; he quotes lyrics recited at the Solomon Island skull-houses (Hocart 1922). The same applies to De Raedt in his record from the Kalinga in the Luzon Cordilleras (De Raedt 1996, 175), and Hoskins from the Indonesian island of Sumba (Hoskins 1996, 229-230).

The Bugkalot do not venerate the head, but other Southeast Asian peoples do. Sahlins, in a note on Southeast Asian ethnographies, writes: 'enemy heads are analogous to stranger-kings' (Sahlins 2012, 140). George gives excerpts from headhunter's songs that contain words of care for dampening the passion (lasting desires) that might linger on with their presence in the village (George 1996b). The words may sound nice, but it is questionable if they express empathy. Could they, rather, be just the 'reenactive forms' covered by other terms such as 'pity,' 'sympathy,' 'compassion' (Hollan and Throop $2011,7)$ ? Or could they simply be plain flattery: words made for cajoling the head into secure growth in the fields? Headhunters' songs, if extant, may answer this question.

M. Rosaldo did not publish headhunters' songs (cf. George 1996b, 12), but could the tunes have rekindled a spirit of the headhunt? A similar contingency is noticeable in Yang: The New Tribes Mission did not encourage recital of celebratory songs, 'lest they tug at their hearts and awaken the old ways' (Yang 2011, 163). The Philippine state may have wanted to churn culture shows out from the headhunting tradition, but according to Yang, a recreation of the buayat celebratory feast 'would evoke strong emotions, pull their hearts, and make them want to kill' (Yang 2011, 179). The Bugkalot resisted this invitation. They seem to have realized that the line between art and action can be tenuous. Celebratory buayat chants may have been no less incendiary than the Rock Around the Clock in the mid-1950s in the West and possibly some heavy metal and rap music thereafter. Could it be that the horror recounted in biographic narratives vanished soon after the kill and that it is the celebration, rather, along with the traditional lyricism and tonalities, that is most distinctly left in memory? Song and dance may turn the lived experience of the kill into a tale.

\section{Connective Heads}

Needham is critical to interjecting ideas about mystical forces as motivating headhunting (Needham 1976). A trope such as Kruyt's zielstof - 'soul-stuff' - has weak ethnographic provenance (Kruyt 1906). Bloch, in a somewhat different vein, nonetheless looks for a connection between taking heads and augmenting vegetal fertility (Bloch 1992). He compares the headhunting Bugkalot (based on M. Rosaldo) with the more peaceful Buid of Mindoro (extracted from Gibson [1986]). He sees a correlation between headhunting and sacrifice: both induce growth as they take place in the context of agricultural ritual. Headhunting, in this view, generates something more transcendental and permanent than agricultural, sacrificial ritual. Headhunters cull vitality from the severed head. Nonheadhunters, in a somewhat less productive mode, cull vitality from sacrifice. In Bloch's assessment, these are alternatives aiming at the same end: invigoration of growth. Fertility defines the conceptual apex. Let me add here a reflection from own fieldwork 


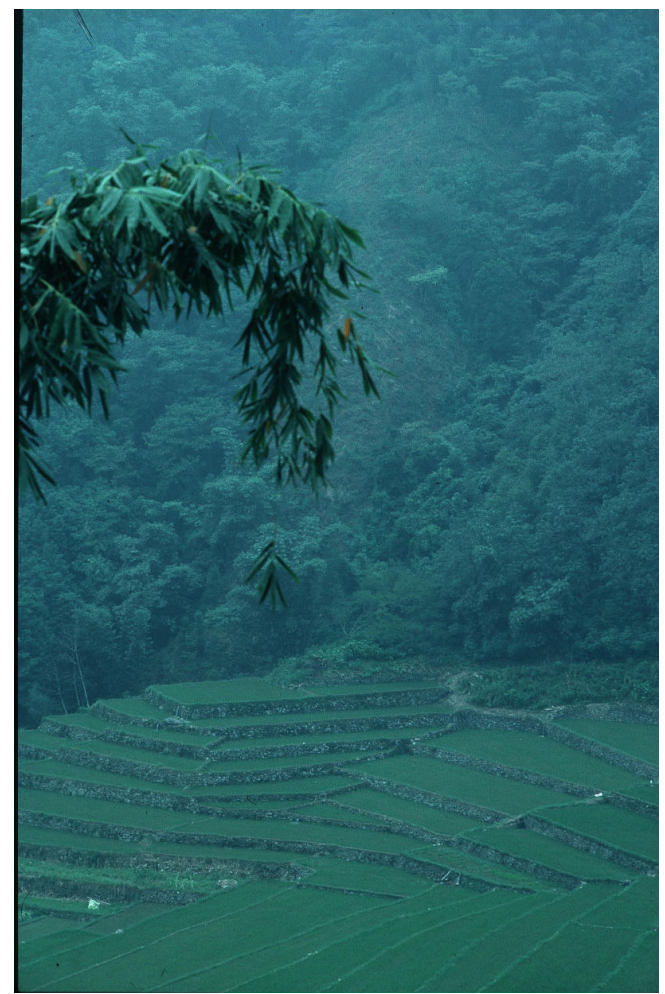

among Austronesian speaking groups: in the highlands of Taiwan (Formosa) and along the foothills on the Aborlan Plain in southern Palawan of the Philippines:

The Bunun in the mountain range of central Taiwan (Røkkum 2002) have a moiety type of kinship arrangement, one that bisects their society. Although phrased in the idiom of exogamous patriclans, I soon realized that extraction in the Bunun group Takibak'ha was not simply inherited. It was often earned, either through commensality on game that had been tabooed by a prior ritualized sprinkling of millet or through the sharing of a skull trophy after going together on a headhunters' raid. (This convergence, incidentally, matches the association of headhunting with game hunting reported by Collier and Rosaldo [1981].) The former Japanese colonialists had forcefully separated the Bunun males from trophy heads stored in niches in stonewalls, by resettling their villages in the present lower ranges of the mountain massif. But the notion lived on, still, when I carried out fieldwork in the early 1980s. Bunun males could enjoy a unique togetherness, one which sets off a rule of exogamy if having celebrated together the taking of a head. The fait accompli makes them a tashitu shidoq, 'oneness as a family.' There is no mystical aspect of fertility here; the Bunun see the taking of a head as the defining act of overriding kinship in the biogenetic sense of father-son relations. It is transcendental only in such pragmatic sense, by continuously refashioning the moiety arrangements of Bunun society. There is no sense here of fertilizing millet, even if that agricultural grain has a definable ontological status among the Bunun.

Among the Tagbanua of Palawan in South Philippines (Røkkum, forthcoming), slashand-burn cultivators of upland rice make the killing of fowls a mandatory act at both the opening and concluding parts of the cycle of tasks. I watched blood dripping on the ground in the ritual announcing the opening of the season. But this - as a metaphoric association all too easy to draw with Western gloss - does not justify a view that fertility to the Tagbanua comes out of blood-stuff. The perspective here is not even human: in the view given as that of the diwata spirits, there is not even anything metaphoric in the 
concatenation of blood and rice. What these spirits actually see when blood drips down is a beautiful red glow. It is precisely here - in such instantaneous switch of view coming with the kill - that we might discern something convergent between headhunting and sacrifice. The split of a second tossing of a human head described by Mikkelsen could also declare a switch in some respect, from face to non-face.

Finally, regarding empathy: the possibility raised by Mikkelsen that cultural patterning can open up for a negative - manipulative - side of empathizing is intriguing if taking into account a default interpretation seeing it as placing oneself in the situation of another. Either way, there is a further question to be addressed, about the social framing of empathy. The ground for empathizing may not uniquely be one of self $=>$ other but rather one of other $=>$ self. In a study of a Polynesian community, the Anuta, in the Solomon Islands, Feinberg concludes that the linguistic term that touches on our concept of 'empathy,' aropa, 'is expressed in overt - usually economic behavior' (Feinberg 2011, 162). This would constitute one example of social framing. In the anthropological project, therefore, we may intercept linguistic projections of what in English goes as 'empathy.' We can also see their concomitants in social life, as among the Tagbanua of Palawan, who practice sharing of rice harvested on their swiddens with those whose crops were ruined by wild pigs, birds, and monkeys (Røkkum forthcoming). This is highly reflexive - resonant - behavior, although sharing here does not match very well categories such as 'empathy' and 'compassion.' Even our word 'sympathy' prioritizes the inward-outward perspective. Tagbanua comments on the habitual assurance of help exclude its relevance for diwan, the strangers (such as settlers in their area). Empathy is bounded in some way.

So how do people draw this line between those worthy of empathy and those who are not? The question to be asked here is about an interiority not of the person but of the group: as empathy is highly alive among people of the same kind but not so much alive among those who are not. The instance could be one of selective empathy; it may mirror the figurations of group boundary. Persson and Savulescu see such non-spontaneous empathy as 'making evolutionary sense' (Persson and Savulescu 2017). But it would be quite facile, I think, to assume ipso facto that inclusion or exclusion is fixed in the way of a 'boundary.' Siverts has illustrated the point in an ethnographic account of the Amerindian Aguaruna Jívaro: 'As headhunters, they recognize only Jivaro heads as worth taking' (Siverts 1978, 216). Group boundaries may give some protection to those on the outside but not to those who are, by birthright, on the inside.

Bugkalot heads were also worth taking, at least there seems to have been no rule against it. As reported by Mikkelsen, Bugkalot headhunters did not target definable Others specifically, such as Christian lowlanders or nearby living Negritos, although Willcox's account, as mentioned above, may suggest that members of these groups had, in fact, had their heads cut off. There may have been no natural enemies. Willcox tells us that Bugkalot may have had few qualms about targeting in-laws: the case he adduces is one of Bugkalot perpetrators and Negrito victims (Willcox 1912). Intermarriage happened between the two groups. One cannot rule out the possibility, therefore, that some killers may have known their victims fairly well. Besides, if the kill were to be carried out as an ambush, some familiarity with terrain would be advantageous as well. That would favor going into neighborhoods. M. Rosaldo, to compare, emphasizes a restraint on targeting people of the same kind as oneself with violence: 'Enmity is often undermined by 
'knowledge' of enduring kinship' (Rosaldo 1980, 208-209). In her account, kinship is the factor that patterns the choices of making a kill or not making a kill. Yang identifies a feuding unit as a 'territorial descent group' (Yang 2011, 163). A further issue is whether the kill would mobilize the victim's descent group for revenge, what Yang identifies as the tobǵat, revenge (Yang 2011, 170).

When Bugkalot male informants give expression of pity and terror (Mikkelsen 2017, 11), the case may well be one in 'which empathy is culturally patterned' (Mikkelsen 2017, 6). Alterity needs to be declared; the Bugkalot headhunter performs this in action by tossing the head. The familiar face of an in-law, for example, is removed once and for all. If fear is an aspect of this, it might well be augmented by the likelihood of retributive violence. The nearer the victim is to the killer, the less likelihood there is that the headhunter would like to tend the cranial remains in a 'skull-house.' The tendency toward in-group killings among Bugkalot may explain why, unlike the case of other ethnographies mentioned in this article, there is no post-mortem interaction with the head. The case here, with no clear in-group versus out-group identification, may not be the one I referred to above as selective empathy but rather, given the nondeterminacy of the kill, be one of reflexive empathy (Persson and Savulescu 2017).

Mikkelsen sees empathy and violence not as antithetical; identification with the other may in fact come as a precursor to violence. In the case of the Bugkalot, aggression happens not before but after the kill. This is what the headhunters themselves recollect. Words of pity also appear in the reminiscences recorded by Mikkelsen. He adduces comparative notes from within the Southeast Asian region: people feed the head, and they wrap it in cloth to guard it against cold. Hollan with a view on an ethnography of the Toraja of Sulawesi asks nonetheless if empathy is 'a luxury that only those with adequate care and resources can afford?' (Hollan 2011, 203). Hoskins (1996, 14) raises some doubts, however, about a generic validity of the humanizing the head observation made by McKinley (1976). Let me intersperse with my own reflection:

People can act with empathy, with sympathy, with pity; but these evocations of interiority can hardly be deemed 'prereflexive.' Depriving the head of its face opens up for treatment of it as an object: as a collectible if stored in a Western museum or as a memento if stored in a Bornean 'head-house,' or a Melanesian 'skull-house.' Even the celebratory framing itself - the artistic enculturation of the kill - might have been so dazzling that there would be little cognitive space for accommodating its (lost) human features. The head would quickly become either a collectible or a memento.

Crapanzano addresses the issue of transgression with a view on the filtering effect on the erotic by the symbolic. His view is about a 'tendency to violate,' but that is not a violation against the 'prereflexive,' but rather quite the opposite, about 'the erotic as symbolic activity' (Crapanzano 2006, 177). Taboo violations involve such symbolic activity; they may be said to go against human nature, but they are inevitably culturally underpinned. Songs of celebration or invocations to spirits, I suggest, may hold these clues as to how matters of aesthetics and romance can quickly stamp out a presentational image of gore.

\section{Conclusion}

This has been a comment on Mikkelsen (2017) and some additional literature. Issues raised in Facehunting deserve further comment and discussion along such conceptual lines 
as 'prereflexivity' and 'transgression.' A question to be addressed, even in a broader view on the nature of violence, is whether the capacity to place oneself in the situation of another - to empathize - is ingrained in human character without, at the same time, tacitly upholding a thesis of 'the psychic unity of mankind.' But even without access to reports of informant emotive interiority in the historical reconstructions of headhunting, it would be possible, I suggest, to study a reverse image of empathy:

Ethnographic record may reveal culturally patterned ways of affixing otherness to a severed head, either this is preconfigured, as in the cases of declared enmities, or impulsive, as in Mikkelsen's portrayal of the Bugkalot case. Defacing the head seems to be one way of reconfiguring it as an illustrious Other. This, in my view, is what makes the act (such as the one of tossing the head in the bush) truly transgressive. Strangeness replaces - felt - familiarity, maybe even empathy. In an extended view on headhunting ethnographies, I have emphasized that the transfiguration of the head, as a memento, a trophy, or an enshrined spirit may hardly warrant any assumption of lasting empathy. A severed head is an object of a culturally assigned treatment that in some cases may not differ very much from obeisance demanded under the norms of religious iconography, not least the sculptured ones. Its defacement might even be what opens up for an emotional multiplexity comprising awe, respect, pity, and of course, horror. But these are modulated feelings, culturally motivated to some degree. The skull has from then on a role to play as an effigy.

Aswani, Shankar. 2000. "Changing Identities: The Ethnohistory of Roviana Predatory Head-hunting." The Journal of the Polynesian Society 109(1): 39-70.

Barton, Roy Franklin. 1919. Ifugao Law. Berkeley CA: University of California Press.

Black, I.D. 1976. "Interethnic Relations and Cultural Change under Colonial Rule: A Study of Sabah." In Studies in Borneo Societies: Social Process and Anthropological Explanation, edited by G. N. Appell. Center for Southeast Asian Studies, Northern Illinois University. (27-43)

Bloch, Maurice. 1992. Prey into the Hunter: The Politics of Religious Experience. Cambridge: Cambridge University Press.

Ghacon, Richard J. and David H. Dye. 2007. The Taking and Displaying of Human Body Parts as Trophies by Amerindians. New York NY: Springer.

Collier, Jane F. and Michelle A. Rosaldo. 1981. "Politics and Gender in Simple Societies." In Sexual Meanings: The Cultural Construction of Gender and Sexuality. Cambridge: Cambridge University Press. (275-329)

Grapanzano, Vincent. 2006. "Transgression and the Erotic." In Celebrating Transgression: Method and Politics in Anthropological Studies of Culture, edited by John Hutnyk and Ursula Rao. Oxford: Berghahn. (165-180)

De Raedt, Jules. 1996. "Buaya Headhunting and its Ritual: Notes from a Headhunting Feast in Northern Luzon." In Headhunting and the Social Imagination in Southeast Asia, edited by Janet Hoskins. Stanford CA: Stanford University Press. (167-183) 
Downs, R. E. 1955. "Head-hunting in Indonesia." Bïdragen tot de Taal-, Land- en Volkenkunde 111(1): 40-70.

Feinberg, Richard. 2011. "Do Anutans Empathize? Morality, Compassion, and the Opacity of Other Minds." In The Anthropology of Empathy: Experiencing the Lives of Others in Pacific Societies, edited by Douglas H. Hollan and Jason Throop. New York NY: Berghahn. (119-167)

Fiske, Alan Page and Tage Shakti Rai. 2015. Virtuous Violence: Hurting and Killing to Create, Sustain, End, and Honor Social Relationships. Cambridge: Cambridge University Press.

Furness, William Henry. 1902. The Home Life of Borneo Head-hunters. Philadelphia PA: J. B. Lippincott.

George, Kenneth M. 1996a. "Lyric, History, and Allegory, or the End of the Headhunting Ritual in Upland Sulawesi." In Headhunting and the Social Imagination in Southeast Asia, edited by Janet Hoskins. Stanford CA: Stanford University Press. (50-126)

George, Kenneth M. 1996b. Showing Signs of Violence: The Cultural Politics of a Twentiethcentury Headhunting Ritual. Berkeley CA: University of California Press.

Gibson, Thomas. 1986. Sacrifice and Sharing in the Philippine Highlands: Religion and Society among the Buid of Mindoro. London School of Economics Monographs on Social Anthropology 57. London: The Athlone Press.

Haddon, Alfred G. 1901. Head-hunters: Black, White, and Brown. London: Methuen.

Hocart, A.M. 1922. "The Cult of the Dead in Eddystone of the Solomons." Fournal of the Royal Anthropological Institute of Great Britain and Ireland 52: 71-112.

Hollan, Douglas H. 2011. "Vicissitudes of 'Empathy' in a Rural Toraja Village." In The Anthropology of Empathy: Experiencing the Lives of Others in Pacific Societies, edited by Douglas H. Hollan and Jason Throop. New York NY: Berghahn. (195-214)

Hollan, Douglas H. and Jason Throop. 2011. "Introduction." In The Anthropology of Empathy: Experiencing the Lives of Others in Pacific Societies, edited by Douglas H. Hollan and Jason Throop. New York NY: Berghahn. (1-21)

Hoskins, Janet. 1996. "Introduction: Headhunting as Practice and as Trope." In Headhunting and the Social Imagination in Southeast Asia, edited by Janet Hoskins. Stanford CA: Stanford University Press. (1-49)

Hviding, Edvard. 1998. "Western Movements in Non-Western Worlds: Towards an Anthropology of Uncertain Encounters." Journal of the Finnish Anthropological Society 23(3): 30-51.

Kruyt, A. G. 1906. Het Animisme in den Indischen Archipel. The Hague: Martinus Nijhoff.

Lumholtz, Carl. 1991 [1920]. Through Central Borneo. Volume 1. New York NY: Charles Scribner's Sons.

McGovern, Janet B. Montgomery. 1922. Among the Head-hunters of Formosa. London: T. Fisher Unwin. 
McKinley, Robert. 1976. "Human and Proud of It! A Structural Treatment of Headhunting Rites and the Social Definition of Enemies." In Studies in Borneo Societies, edited by G. Appell. DeKalb IL: Center for Southeast Asian Studies. (92-126)

McKinnon, Susan. 1991. From a Shattered Sun: Hierarchy, Gender and Alliance in the Taninbar Islands. Madison WI: University of Wisconsin Press.

Metcalf, Peter. 1982. A Borneo Fourney into Death: Berawan Eschatology from Its Rituals. Philadelphia PA: University of Pennsylvania Press.

Mikkelsen, Henrik Hvengaard. 2017. "Facehunting: Empathy, Masculinity and Violence among the Bugkalot." Fournal of Extreme Anthropology 1(3): 5-17

Millman, Lawrence. 1998. An Evening Among Headhunters: \& Other Reports from Roads Less Traveled. Cambridge MA: Lumens Editions.

Needham, Rodney. 1976. "Skulls and Causality," Man (ns) 2: 71-88.

Persson, Ingmar and Julian Savulescu (2017) "The Moral Importance of Reflexive Empathy." Neuroethics https://ora.ox.ac.uk/objects/uuid:ac1ca022blf7-45f2-9f08-97alea2e67cb.

Røkkum, Arne. (forthcoming). Material Signs: A Shamanic Order in South Philippines.

Røkkum, Arne. 2002. "Meat and Marriage: An Ethnography of Aboriginal Taiwan." Bulletin of the National Museum of Ethnology [Osaka] 26(4): 707-737.

Røkkum, Arne. 1991. "The Pig and the Flying-fish: Performative Aspects of Yami Culinary Categories." in The Ecology of Choice and Symbol: Essays in Honour of Fredrik Barth, edited by R. Grønhaug et. al. Bergen: Alma Mater. (258-279)

Roque, Ricardo. 2010. Headhunting and Colonialism: Anthropology and the Circulation of Human Skulls in the Portuguese Empire, 1870-1930. Basingstoke: Palgrave Macmillan.

Rosaldo, Michelle Z. 1980. Knoweledge and Passion: Ilongot Notions of Self and Social Life. Cambridge: Cambridge University Press.

Rosaldo, Renato. 2004. "Grief and the Headhunter's Rage." In Death, Mourning, and Burial: A Cross-cultural Reader, edited by Antonius C. G. M. Robben. Malden MA: Blackwell Publishing (167-178).

Rosaldo, Renato. 1980. Ilongot Headhunting 1883-1974: A Study in Society and History. Stanford CA: Stanford University Press.

Roth, Henry Ling. 1896. The Natives of Sarawak and British North Borneo: Based Chiefly On the Mss. of the Late H. B. Lowe, Sarawak Government Service, Vols 1-2. London: Truslove and Hanson.

Rousseau, Jérôme. 1990. Central Borneo: Ethnic Identity and Social life in a Stratified Society. Oxford: Clarendon Press.

Sahlins, Marshall. 2012. "Alterity and Autochthony: Austronesian Cosmographies of the Marvelous." Hau: Fournal of Ethnographic Theory 2(1): 131-160. 
Siverts, Henning. 1978. "Jivaro Headhunters in a Headless Time." In Perspectives on Ethnicity, edited by Regina E. Holloman and Serghei A. Arutiunov. The Hague: Mouton Publishers. (127-138)

Tsing, Anna Lowenhaupt. 1996. "Telling Violence in the Meratus Mountains." In Headhunting and the Social Imagination in Southeast Asia, edited by Janet Hoskins. Stanford CA: Stanford University Press. (184-215)

Valeri, Valerio. 1994. "Hunting as Sacrifice and Sacrifice as Hunting in Huaulu." History of Religions 34(2): 101-131.

van der Kroef, Justus M. 1952. "Some head-hunting traditions of Southern New Guinea." American Anthropologist 54: 221-35.

Waite, Deborah. 2000. "An Artefact / Image Text of Head-hunting Motifs." The Journal of the Polynesian Society 109(1): 115-144.

Wikan, Unni. 2013. Resonance: Beyond the Words. Chicago IL: University of Chicago Press.

Willcox, Cornélis De Witt. 1912. The Head Hunters of Northern Luzon: From Ifugao to Kalinga - A Ride through the Mountains of Northern Luzon, With an Appendix on the Independence of the Philippines. Kansas City MO: Franklin Hudson Publishing.

Yang, Shuh-yuan. 2011. "Headhunting, Christianity, and History among the Bugkalot (Ilongot) of Northern Luzon, Philippines.” Philippine Studies 59(2): 155-186.

Arne Røkkum is a Professor Emeritus of Social Anthropology at the Museum of Cultural History, University of Oslo. He has carried out fieldworks in the Izu Islands of Japan, in the southern Ryuykyus (of Okinawa Prefecture, Japan), in Taiwan among the Austronesian speaking Bunun and the Yami, and recently among the Tagbanua [Tagbanwa] in southern Palawan, Philippines. He has written two field monographs (1998 and 2006) on ritual life in the Ryukyus, focusing on a female partnership (as sister) in authority roles prevailing since the age of the Ryukyu kingdom. His forthcoming Material Signs: A Shamanic Order in South Philippines lays out a pattern of shamanic ritual, along a full year-cycle of planting tasks in a group of Tagbanua slash-and-burn cultivators. It addresses issues of animism and perspectivism. Contacting author: arne.rokkum $@$,khm.uio.no 